\title{
The influence of learning model and learning independence on mathematics learning outcomes by controlling students' early ability \\ Dodik Mulyono
}

STKIP-PGRI Lubuklinggau, INDONESIA

\begin{abstract}
The aims of this research are; (1)Differences in mathematics learning outcomes of students learning with reciprocal teaching and student facilitator and explaining, (2)The effect of interaction between learning model and learning independence on mathematics learning outcomes in students, (3)Differences in student learning outcomes that have high learning independence by learning model reciprocal teaching and student facilitator and explaining, (4)Differences in learning outcomes of students who have low learning independence who learn with reciprocal teaching and learning with student facilitator and explaining. The research method used is experimental method. The result of hypothesis, (1)testing shows that $\mathrm{HO}$ is rejected, (2)testing shows that $\mathrm{HO}$ is rejected, (3)testing shows that $\mathrm{HO}$ is rejected, (4)testing shows that $\mathrm{HO}$ is rejected.
\end{abstract}

KEYWORDS

Learning Independence, Learning Models, Initial Abilities
ARTICLE HISTORY

Received 10 August 2017

Revised 28 August 2017 Accepted 25 September 2017

\section{Introduction}

Learning model Reciprocal teaching is a model of learning through the activities of teaching friends. This model makes students play a role as teacher to replace the role of teacher to teach his friends. Teachers play a role as model for example, facilitator (giving facilities) that provide ease and guidance that do scaffolding.

Learning Model Student Facilitator and Explaining is a learning model of students learning to present ideas, opinions or ideas about the subject matter to other students. Learning cannot work well without the participation of students.

\section{CORRESPONDENCE Dodik Mulyono $\square$ dodikmulyono81@gmail.com}

(C) 2017 D. Mulyono

Open Access terms of the Creative Commons Attribution 4.0 International License apply. The license permits unrestricted use, distribution, and reproduction in any medium, on the condition that users give exact credit to the original author(s) and the source, provide a link to the Creative Commons license, and indicate if they made any changes. (http://creativecommons.org/licenses/by/4.0/) 
By making the student as a facilitator and invited creative thinking so as to generate more in-depth information exchange.

The independence of learning is the perception or outlook of a person toward himself, which is formed through experience and interaction with the environment and is influenced of the people who are considered important, by improving the independence of student learning is the better the independence of learning will have an impact on the ability and results of learning so vice versa. For that support the learning environment when it is very necessary by using the models of appropriate learning.

Initial abilities are learning outcomes gained before gaining higher abilities. Early ability of students is a prerequisite to be able to follow the learning so that it can carry out the learning process with both the initial ability of students is important for educators in order to determine the initial limits of student ability appropriately.

The results of preliminary study at SMP Negeri Marga Baru, the learning model applied to the math lesson at SMP Negeri Marga Baru with lectures and assignments. The learning models used by teachers have not been varied tend to be monotonous. The conventional learning model makes the student activity more listening and record the material given by the teacher, so that students are less active to learn or centered on teachers and students tend to feel bored. It becomes one of the factors causing student learning outcomes do not reach the minimum completeness criteria defined school.

Based on the description above, it is necessary to conduct research on the influence of learning model of reciprocal teaching, learning model of facilitator and explaining and self-learning by controlling students' early ability in learning mathematics

\section{Learning Model Student Facilitator and Explaining}

Learning Model Student Facilitator and Explaining is a collaborative learning activity that teachers can use in the middle of the lesson so as to avoid the way of teaching that is always dominated by teachers in learning. Model student facilitator and explaining is how the teacher is able to present or demonstrate the material in front of the student then give the student the opportunity to explain to his or her friends. Through collaborative learning activities (collaboration) students are expected to acquire knowledge, skills, and attitudes actively. In the model Student Facilitator and Explaining students learn to present ideas to other colleagues. Such learning will train students to speak to convey their own ideas or opinions.

According to (Lei, 2010) student facilitator and explaining is a learning where students present ideas or opinions on other students. By making the student as a facilitator and invited creative thinking so as to generate more indepth information exchange. In line with the above explanation Imas and Berlin student learning model facilitator and explaining is a learning model that trains students to be able to present their ideas or ideas to their friends.

Student facilitator and explaining, students present ideas or opinions to other fellow participants. In this model students learn to talk ideas and ideas. Model student facilitator and explaining in its technical implementation include; 
(1) the teacher conveys the competence to be achieved; (2) the teacher explains or presents the outlines of instructional materials; (3) provide opportunities for students to explain to other students, for example through charts or concept maps; (4) the teacher concludes the student's ideas or opinions; (5) the teacher explains all the material presented as a conclusion and then closes the lesson as it should.

Based on the explanation above can be concluded model Student Facilitator and Explaining is how the teacher is able to present or demonstrate the material in front of students and then give the opportunity to the students to explain to his friends.

\section{Learning Independence}

Independence of student learning is the extent to which in the learning process students can come to determine the objectives, materials and learning experiences, and evaluation of learning. (Fisher in Williams, 2003) discusses ways to create an effective community for learning and demonstrate that an independent learning environment should develop a climate in which important people and respect groups create trust, support and communication.

An independent person can make his own choices responsibly when he wants to learn or what he wants to learn. Such an opinion the first important step before self-learning skills can be developed for students is to understand the need to change. Unless they see this need and desire change, students have no reason to change their approach or any motivation to overcome old habits (Virginia, Louise, 2007).

Self-directed learning according to (Johnson, 2009) frees students to use their own learning styles, advance in their own pace, explore their personal interests, and develop their talents using the multiple intelligences they like. Independent learning is closely related to the 'self-understanding' itself. Students have a 'self-organizing' or 'self-ordered' personality type. They make their own decisions and accept responsibility for it.

(Fridani and Lestari, 2009) states, the principle of independence in learning means that in teaching and learning activities, as early as possible developed independence. The realization of the principle of self-reliance in learning will place the teacher in the lead role as a facilitator and motivator.

Based on the explanation above, the independence of learning is to liberate students to use student learning styles, advance in their own pace, explore their personal interests, and develop their talents using the multiple intelligences they like.

\section{Initial Ability}

Basically the ability that exists within a person can be understood in two aspects, namely the aspect of the visible and the invisible aspect. The apparent ability is the performance competence that can be observed directly by the senses of others. Unseen abilities are rational competencies better known in Bloom's taxonomy as cognitive, affective. and psychomotor. Initial ability is the knowledge and skills that students have before continuing the next level. (Dick, Carey, and Carey, 2009) say early knowledge is a set of skills students should have before they follow a new learning process. 
Based on the explanation above, the initial ability is the result of learning obtained before continuing the next stage and is the authorized capital of students to learn every new subject matter that will be presented by the teacher.

\section{Research method}

The research was done by quantitative approach, using experimental research method. According to gay in emzir, the experimental research method is the only research method that can correctly test hypotheses regarding causal relationships (Emzir, 2008). This research puts the result of mathematics learning as the dependent variable (criterion variable), the learning model (treatment variable) as the first independent variable: the independence of learning with the scale of numerical data grouped in stratum (leveled) into high and low category as attribute free variable (independent variable second), and early mathematical abilities with numerical data scales as covariate-free variables.

\section{Result and Discussion}

\section{Results of Student Group Mathematics Learning with Reciprocal Teaching Model (YA1)}

Results of learning groups of students who learn with the reciprocal teaching model as follows. Number of respondents 32. Minimum value 47 and maximum value 98 so that the data range $98-47=51$. Furthermore the data is presented in the form of frequency distribution table with the number of class 6 , interval width 9, 64,94 average with standard deviation 12.14 ; mode 68 and median 65.0. Visually with the following histogram view.

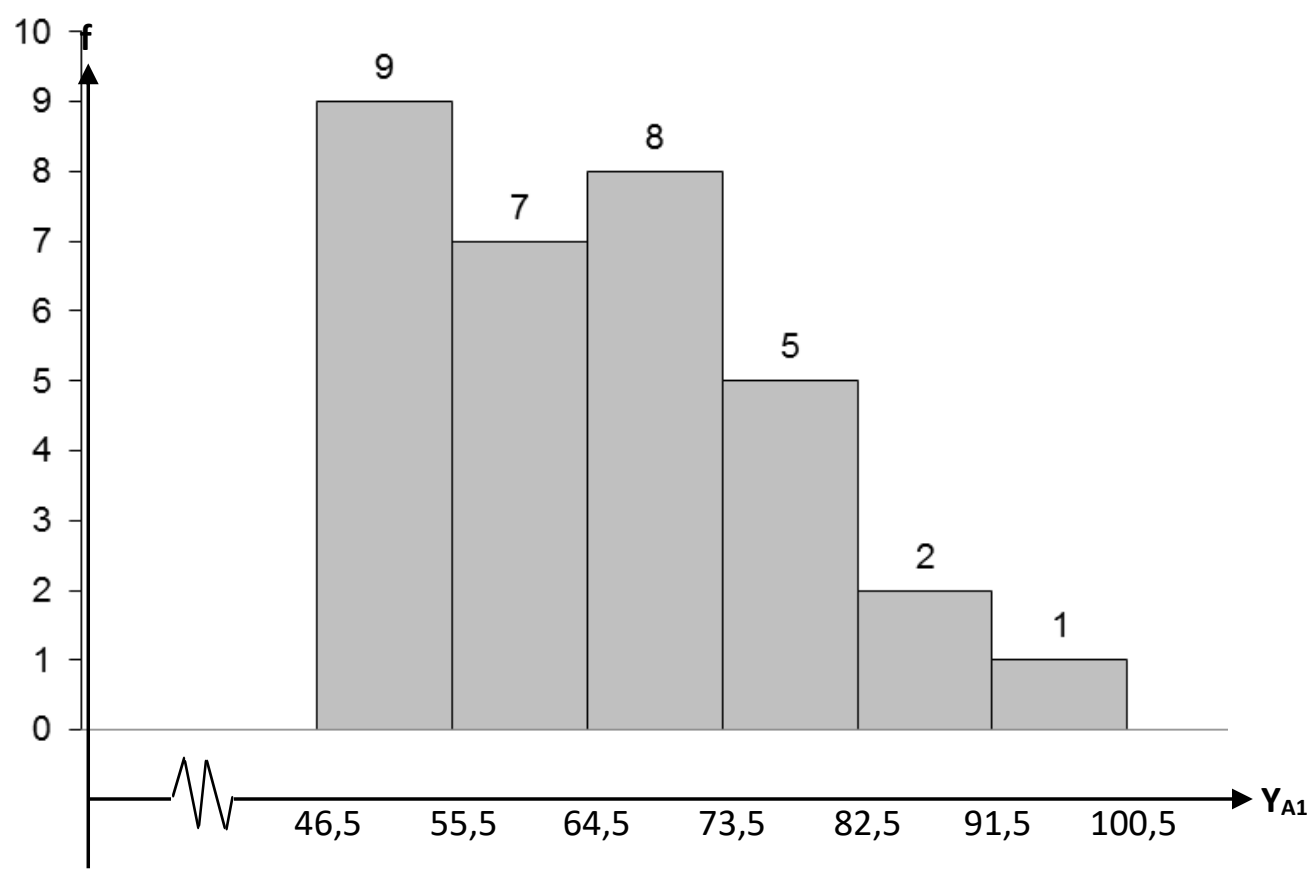


Figure 1. Histogram Data Nilai $Y_{A 1}$ (XA1)

Initial Ability of Student Groups Learning by Reciprocal Teaching Model

Early ability of groups of students who study with the reciprocal teaching model as follows. Number of respondents 32 . The minimum value of 37 and the maximum value 76 so that the data range $76-37=39$. Furthermore the data is presented in the form of frequency distribution table with the number of class 6 , interval width 7, 59.13 average with standard deviation 12.60 ; mode 63 and median 59.0. Visually with the following histogram view.

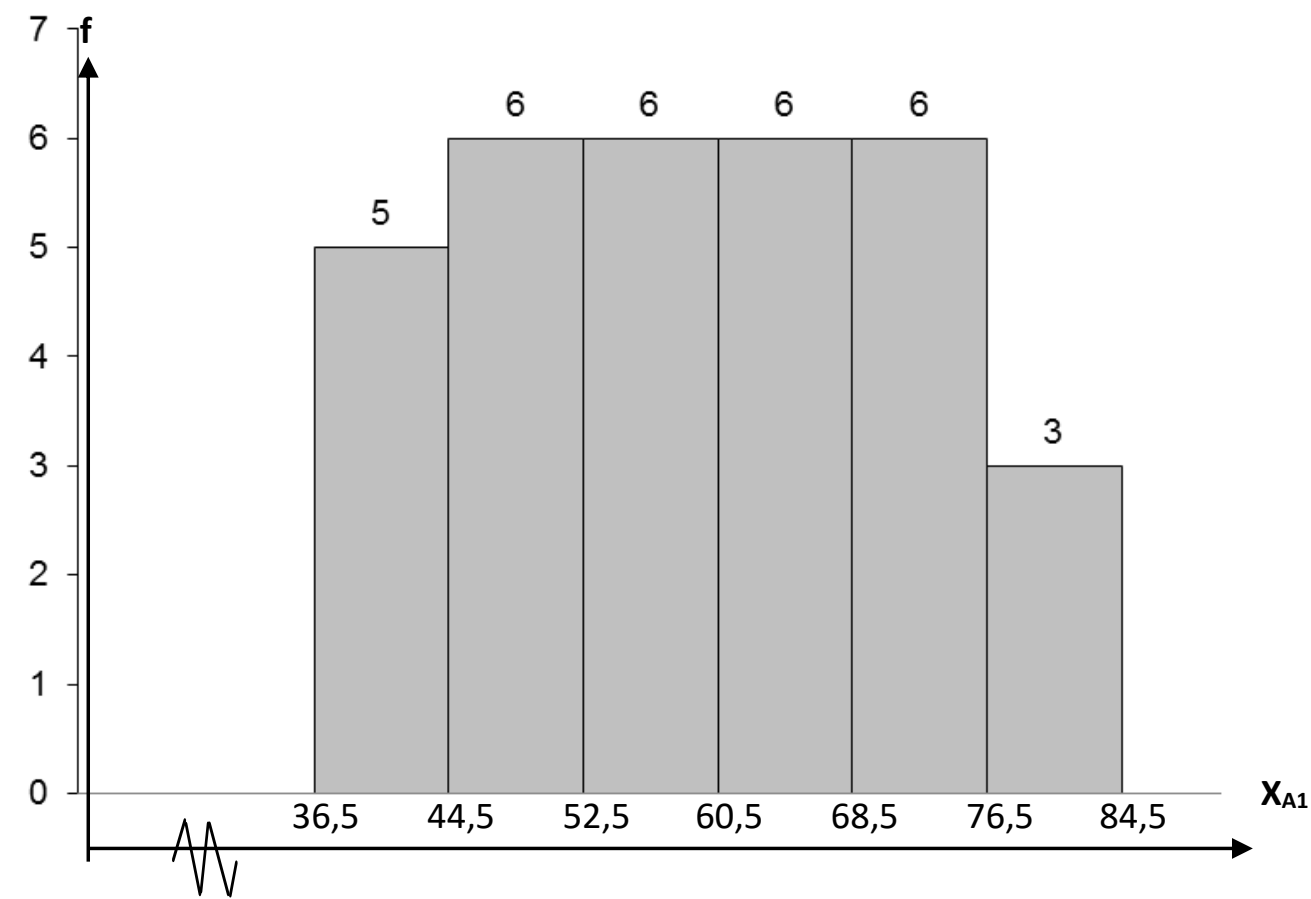

Figure 2. Histogram XA1 Value Data

Results of Student Facilitation and Explaining Student Faculty Student Learning Element (YA2)

6 Student group learning outcomes studied with student facilitator and explaining model as follows. Number of respondents 32 . The minimum value of 40 and the maximum value 79 so that the data range $79-40=39$. Furthermore the data is presented in the form of frequency distribution table with the number of class 6 , interval width 7, 59.06 average with standard deviation 9.09 ; mode 55 and median 57.0. Visually with the following histogram view. 


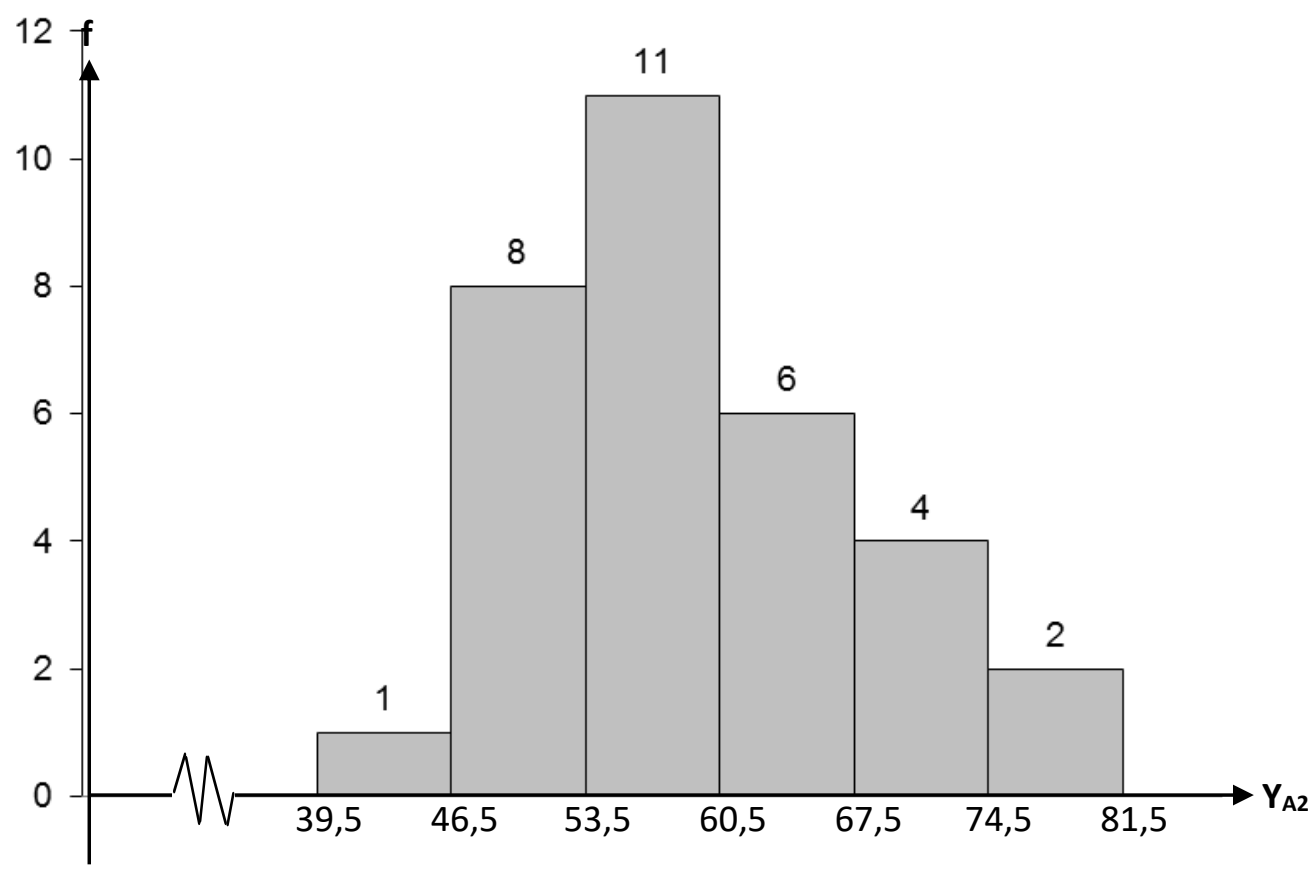

Figure 3. Histogram $\mathrm{Y}_{\mathrm{A} 2}$ Value Data

Initial ability of group of students studying with student facilitator and explaining model as follows. Number of respondents 32 . The minimum value of 37 and the maximum value 76 so that the data range $76-37=39$. Furthermore the data is presented in the form of frequency distribution table with the number of class 6 , interval width $7,54.44$ average with standard deviation 11.72 ; mode 57 and median 55.5. Visually with the following histogram view. 


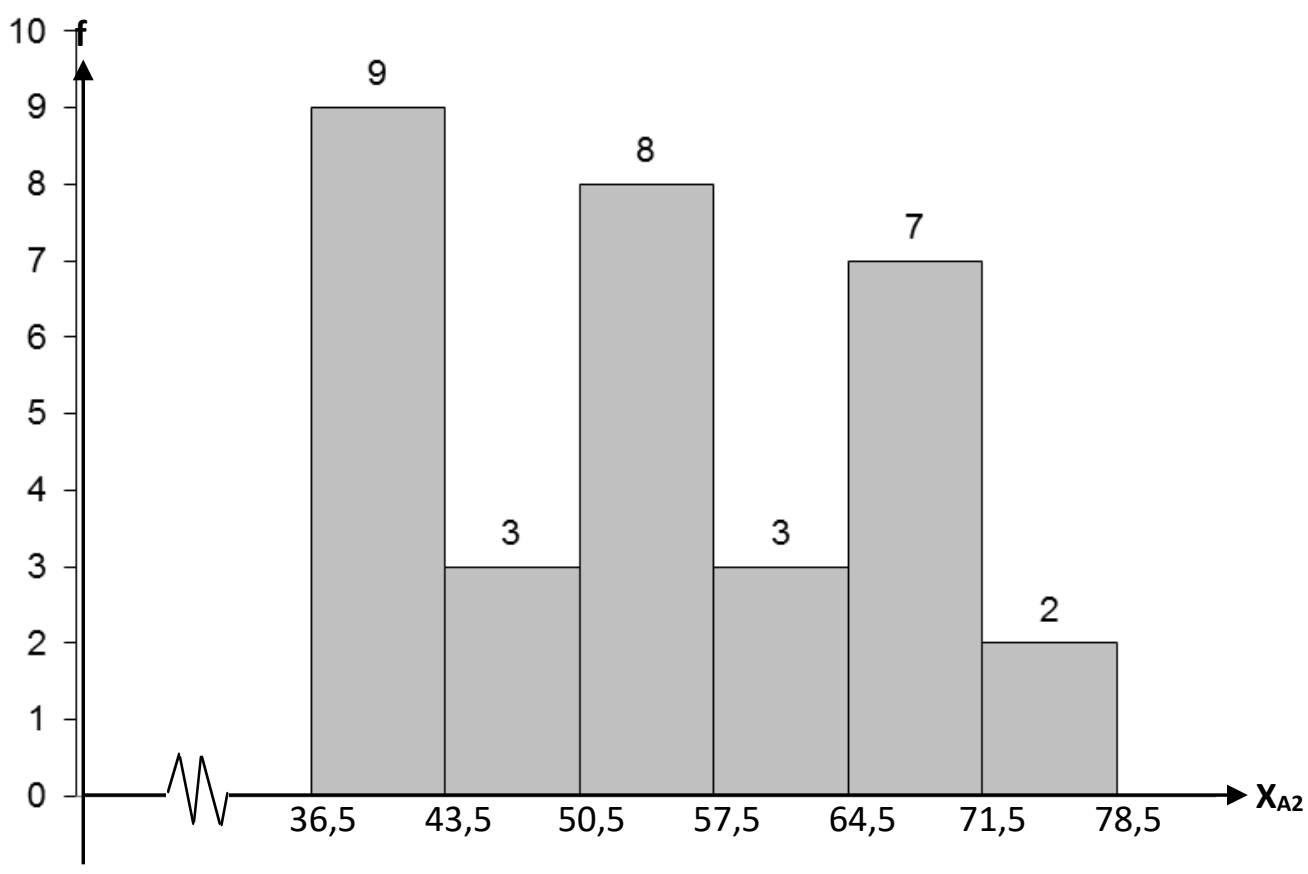

Figure 4. Histogram Data $\mathrm{X}_{\mathrm{A} 2}$

5.4 Results of Student Group Mathematics Learning with Reciprocal Teaching Models and Having Higher Learning Independence (YA1B1)

Results of learning groups of students who study with the reciprocal teaching model and have independence of high learning as follows. Number of respondents 16. Minimum value 64 and maximum value 98 so that the data range $98-64=34$. Furthermore the data is presented in the form of frequency distribution table with the number of class 5 , interval width 7 , average 74.31 with standard deviation 8.88 ; mode 68 and median 73.0. visually with the following histogram view.

view. 


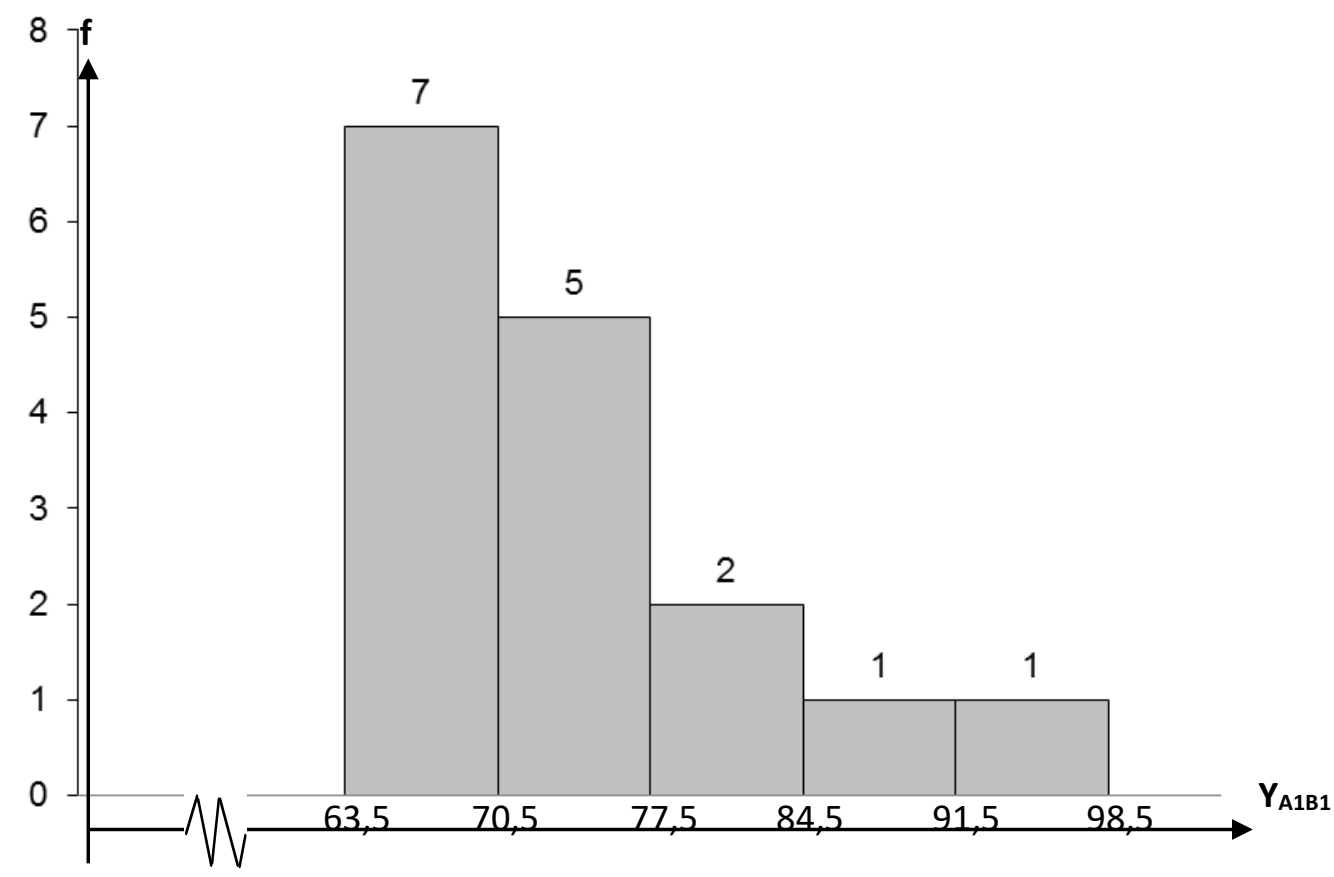

Figure 5. Histogram Data Nilai $Y_{\text {A1B1 }}$

5.5 Initial Ability of Student Groups Learning by Reciprocal Teaching Model and Having High Learning Independence (XA1B1)

Initial ability of group of students who learn with reciprocal teaching model and have independence of high learning as follows. Number of respondents 16 . Minimum score 50 and maximum score 83 so the data range 83 - $50=33$. Furthermore the data is presented in the form of frequency distribution table with the number of class 5 , interval width 7 , average 68.06 with standard deviation 9.32 ; mode 74 and median 71.0. Visually with the following histogram view. 


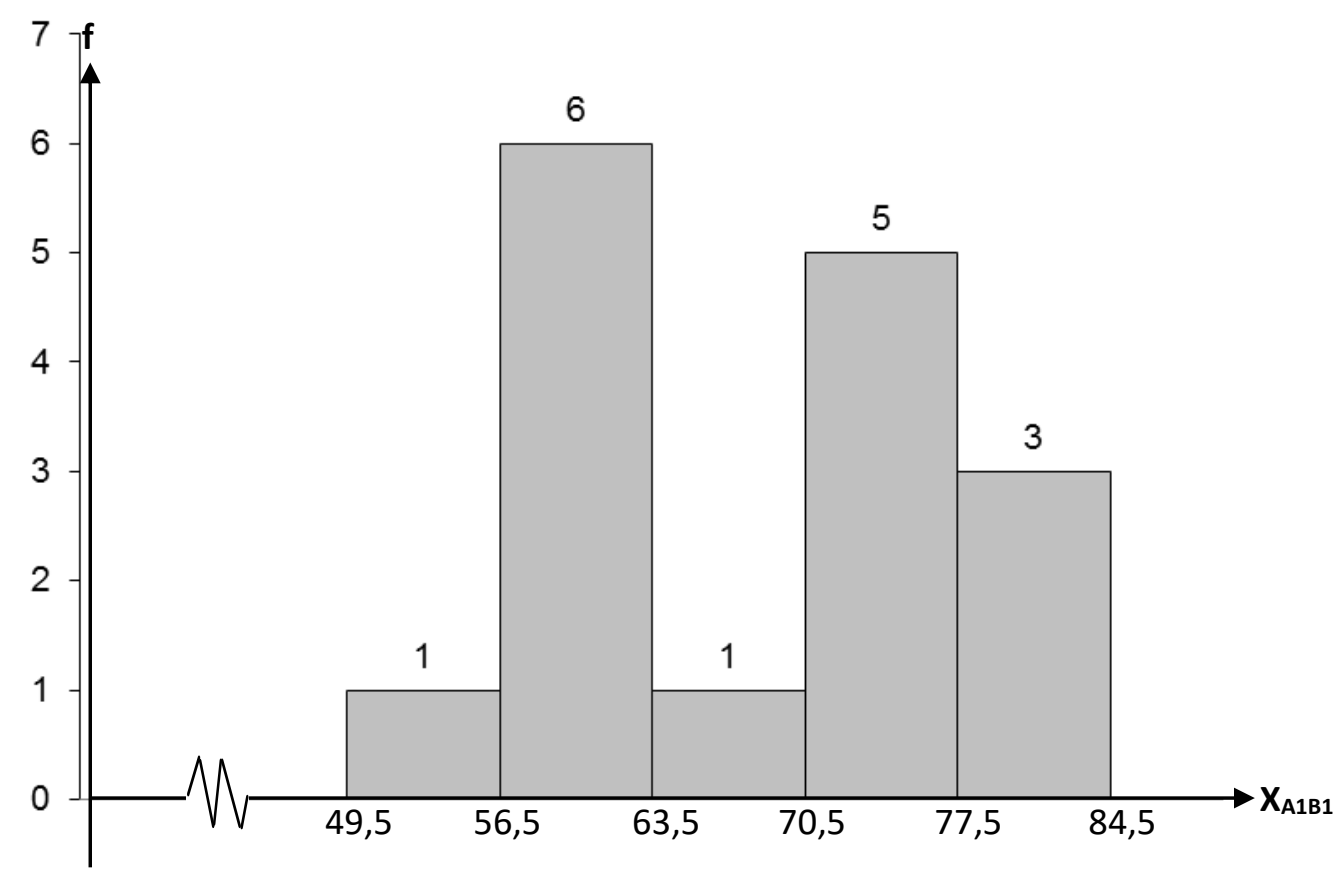

Figure 6. Histogram Data $\mathrm{X}_{\mathrm{A} 1 \mathrm{~B} 1}$

5.6 Learning Outcomes of Student Group Student Facilitation and Explaining Student Facilitation and Explaining and Having Higher Learning Independence (YA2B1)

Results of learning groups of students who studied with student facilitator and explaining model and have independence of high learning as follows. The number of respondents 16 . The minimum value of 47 and the maximum value 66 so that the data range $66-47=19$. Furthermore the data is presented in the form of frequency distribution table with the number of class 5 , interval width 4 , 59.06 average with standard deviation 9.09 ; mode 55 and median 57.0. Visually with the following histogram view. 


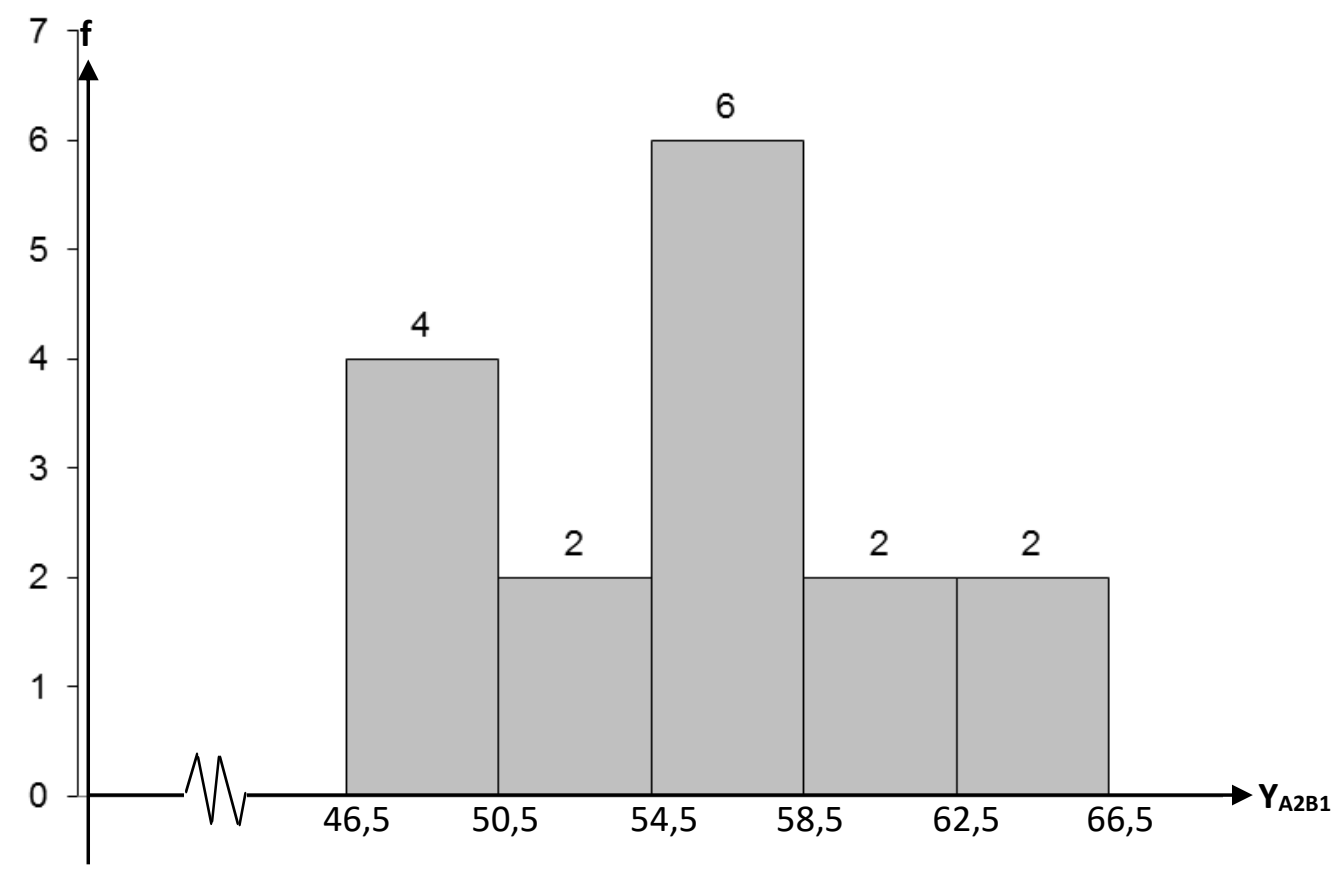

Figure 7. Histogram Data Value YA2B1

5.7 Initial Ability of Student Group Learning by Model Student Facilitator and Explaining and Having High Learning Independence (XA2B1)

Initial ability of group of students studying with student facilitator and explaining model and having high learning independence as follows. The number of respondents 16 . The minimum value of 37 and the maximum value of 70 so that the data range $70-37=33$. Furthermore the data is presented in the form of frequency distribution table with the number of class 5 , interval width 7 , average 49.63 with standard deviation 9.27 ; mode 57 and median 51.0. Visually with the following histogram view. 


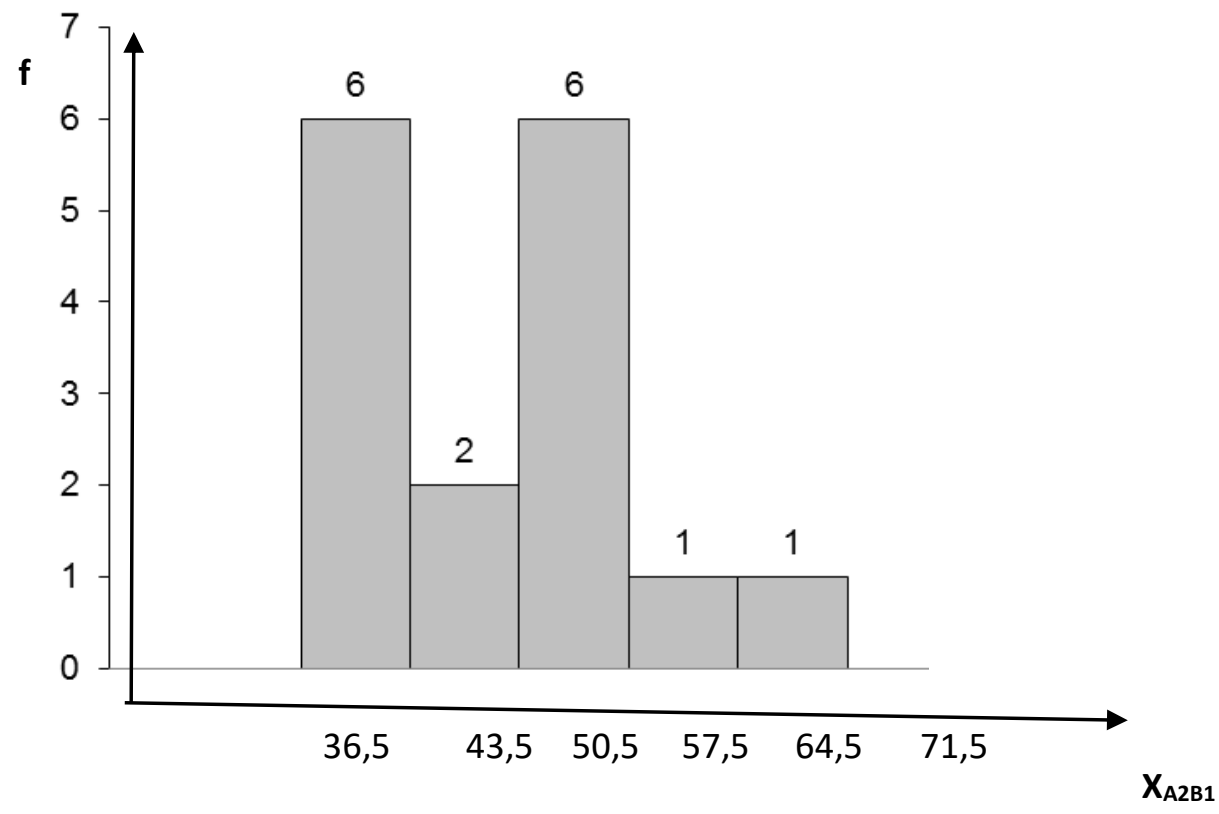

Figure 8. Histogram Data Value XA2B1

5.8 Learning Outcomes of Student Group Mathematics Learning with Reciprocal Teaching and Self-Reliance Models Learning Low (YA1B2)

Results of learning groups of students who learn with the reciprocal teaching model and have independence of low learning as follows. Number of respondents 16. Minimum value 47 and maximum value 66 so that the data range $66-47=19$. Furthermore the data is presented in the form of frequency distribution table with the number of class 5, interval width 4, 55.56 average with standard deviation 6.20 ; mode 53 and median 54.0. Visually with the following histogram view. 


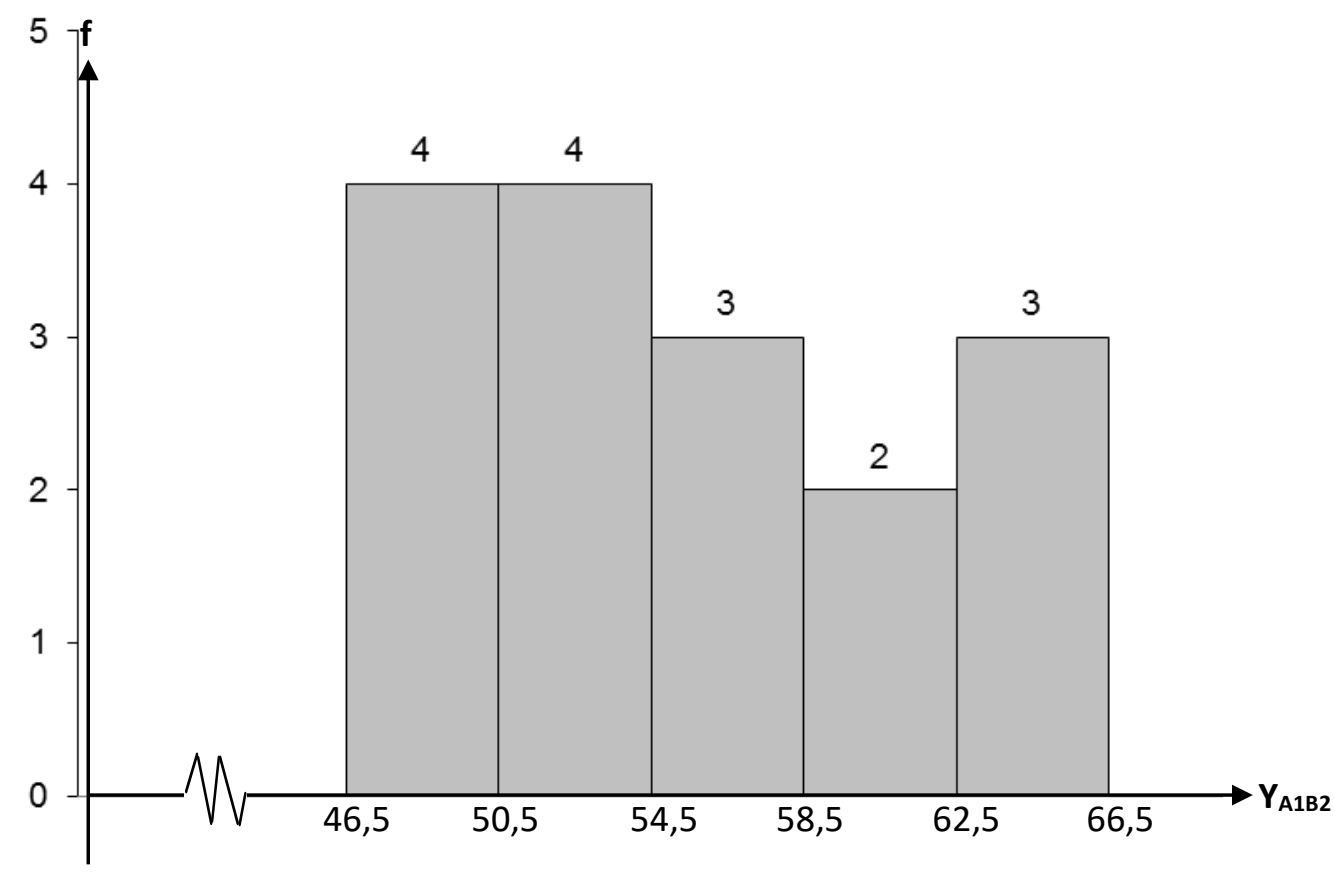

Figure 9. Histogram Data Value YA1B2

5.9 Initial Ability of Student Groups Learning by Reciprocal Teaching Model and Having Low Learning Independence (XA1B2)

Initial ability of groups of students studying with reciprocal teaching models and having low learning independence as follows. The number of respondents 16. The minimum value of 37 and the maximum value of 65 so that the data range is $65-37=28$. Furthermore the data is presented in the form of frequency distribution table with the number of class 5, interval width 6 , average 50.19 with standard deviation 8.41 ; mode 43 and median 49.0. Visually with the following histogram view. 


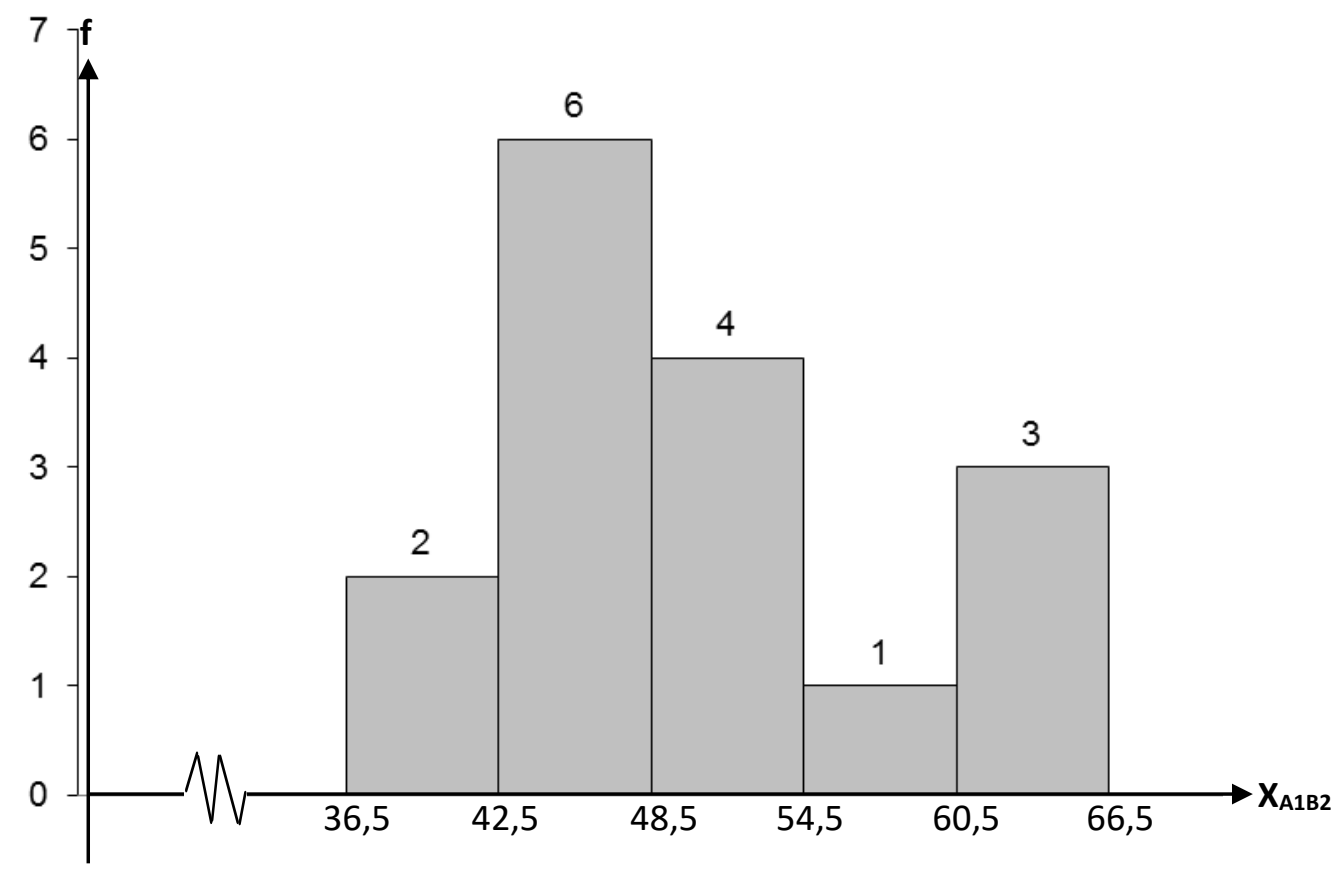

Figure 10. Histogram XA1B2 Value Data

5.10 Learning Outcomes of Student Group Student Facilitation and Explaining Student Facilitation and Explaining and Having Low Self-Reliance (YA2B2)

Results of learning groups of students who studied with student facilitator and explaining model and have the independence of low learning as follows. The number of respondents 16 . The minimum value of 40 and the maximum value of 79 so that the data range $79-40=39$. Furthermore the data is presented in the form of frequency distribution table with the number of class 5 , interval width $8,62.88$ average with standard deviation 6.20 ; mode 53 and median 54.0. Visually with the following histogram view. 


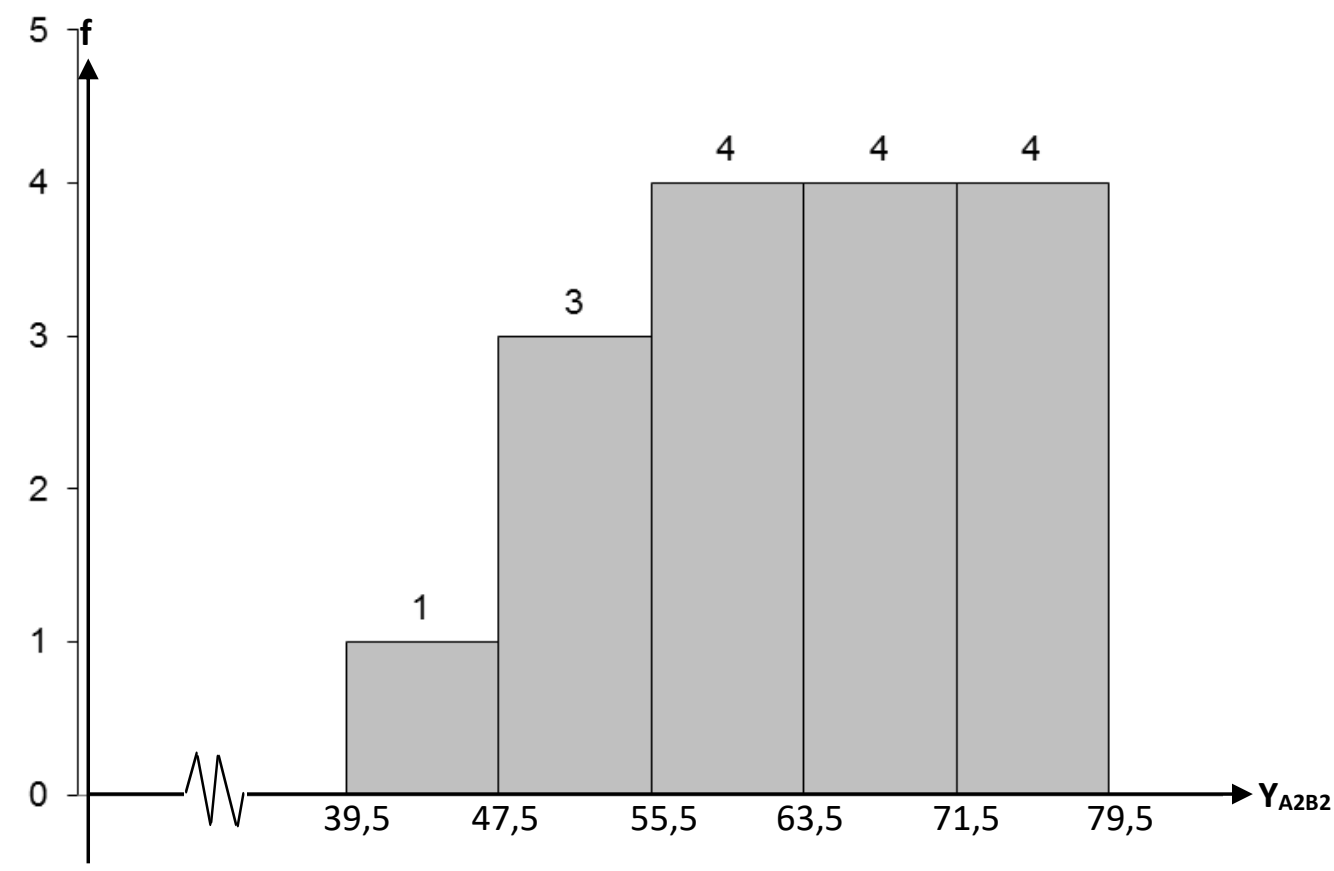

Figure 11. Histogram Data Value YA2B2

5.11 Initial Ability of Student Group Learning by Model Student Facilitator and Explaining and Having Low Learning Independence (XA2B2)

Initial ability of groups of students studying with student facilitator and explaining model and having low learning independence as follows. The number of respondents 16 . The minimum value of 37 and the maximum value 76 so that the data range $76-37=39$. Furthermore the data is presented in the form of frequency distribution table with the number of class 5 , interval width $8,59.25$ average with standard deviation 12.19 ; mode 65 and median 64.0. Visually with the following histogram view. 


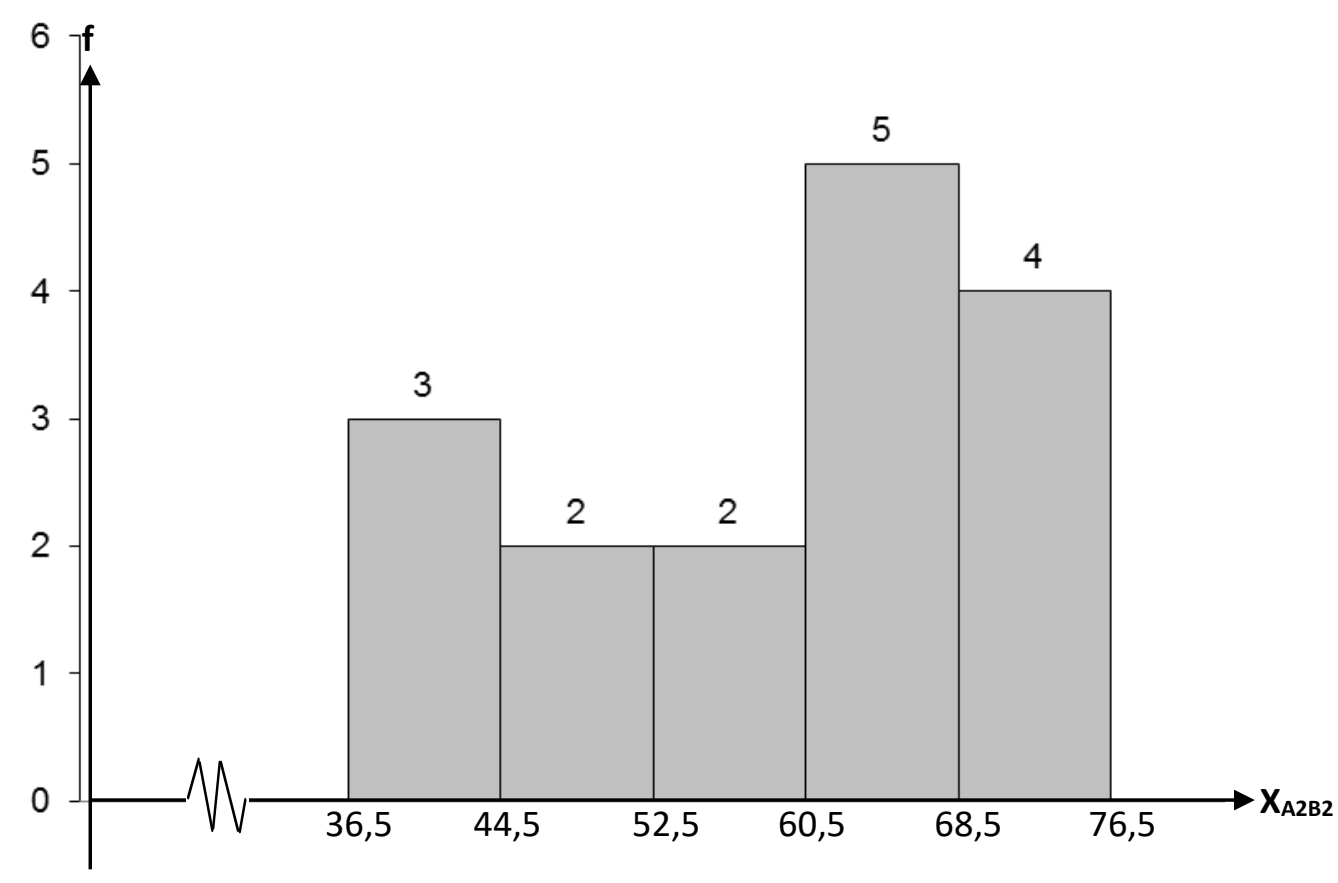

Figure 12. Histogram Data $\mathrm{X}_{\mathrm{A} 2 \mathrm{~B} 2}$

\section{Discussion}

1. The result of the students' mathematics learning that was followed by the learning model of reciprocal teaching was higher than the result of the students' mathematics learning which was taught using student facilitator and explaining model, after controlling the students' early ability

The general purpose of this study is to obtain a more complete picture of the effect of learning model treatment and learning independence on students 'mathematics learning outcomes after controlling students' early abilities.

Based on the results of the two-lane covariance analysis on the first row (Between $\mathrm{A}$ ) it is found that $\mathrm{F}$ arithmetic is greater than $\mathrm{F}$ table $(\mathrm{F}$ Count $=$ $4.47>\mathrm{F}$ Table $(0.05)(1 ; 59)=4.00)$. This shows that students 'mathematics learning outcomes have significant differences between those who study with the reciprocal teaching model and those who study with student facilitator and explaining model after controlling students' early ability. This difference is indicated by the mean value of corrected mathematics learning outcomes of students who studied with the reciprocal teaching model of 64.71 and students' mathematics learning outcomes with student facilitator and explaining model of 59.29 .

This means that there are differences in mathematics learning outcomes of students who study with reciprocal teaching model and mathematics learning outcomes of students who studied with student facilitator and explaining model after controlling students' early ability. 
The proof of this hypothesis is based on the empirical study that researchers do based on the support of theory and concepts as stated in chapter II that Reciprocal Teaching is one of the learning models implemented so that the learning objectives are achieved quickly through independent learning process and the students are able to present in front of the class. According to Arend reciprocal teaching convey to all students that they can learn, that all students can contribute to the learning process, and that all perspectives are rewarded.

According to Muslimin Ibrahim, the influence of reciprocal teaching on learning outcomes is very diverse, among others, affect communication skills, motivation, learning achievement, and cognitive learning outcomes). Through identifying the important things in the reading or the material to be read to determine the important ideas of the materials or materials so that students can determine what students need to be able to achieve the learning objectives.

The results of this study are in harmony with research conducted by Namaghi and Shahhosseini concluding that learning reciprocal teaching can improve students' activeness to build meaning and increase interaction among students inside and outside the classroom. In this study, they compared the influence of the learning model of reciprocal teaching with the transmission learning model. Based on the comparison of pre-test and post-test results of both experimental groups it is known that the learning outcomes of the group of students with reciprocal teaching learning is higher than the group that is taught by the transmission learning model.

Subsequent research was conducted by $\mathrm{Al}$-Harby entitled "The Effect of Reciprocal-Teaching Strategy on Learning Outcomes and Attitudes of QassimUniversity Students in" Islamic Culture ". This study aims to determine the effectiveness of the model reciprocal teaching on learning outcomes and student attitudes compared to traditional learning models at Qassim-University Saudi Arabia. The results of this study indicate that the learning model of reciprocal teaching can: 1) develop dialogue and convergence skills, 2) suitable for learning in large classes, 3) improve student learning achievement in all courses, 4) improve students' increase the level of student activeness and interaction, and 6) increase student self-confidence in learning.

Learning Reciprocal Teaching is a model of learning through the activities of teaching friends. In this model the students play a role in replacing the role of teachers to teach their friends. In the meantime the teacher acts more as an example model, facilitating facilitator, and scaffolding coach, which means giving students a large amount of help during the early stages of learning and then gradually reducing the aid and providing opportunities for the learning child to assume greater responsibility as soon as possible. This model can improve students' activity in learning, build understanding of meaning and improve interaction among students.

2. For students with high learning independence, the results of learning mathematics students learning with learning model reciprocal teaching is higher than that given model student facilitator and explaining, after controlling the student's early ability. 
Results of $\mathrm{t}$-test on students who have high learning independence, $\mathrm{t}$ count $=4.90$ is greater than $\mathrm{t}$ table $(0.01 ; 59)=2.39$. This means that there are differences in mathematics learning outcomes of students who study with reciprocal teaching models and who study with models for groups of students who have high learning independence. Thus it can be concluded that the result of learning mathematics of students who have high learning independence, in the group of students who learn with the reciprocal teaching model higher than the group of students who studied with student facilitator and explaining model after controlling the initial ability $(73,18>55,97)$.

The matter above is in accordance with the results of learning mathematics group of students who were taught using a reciprocal teaching learning model with high learning independence with a corrected average of 73.18. While the group of students who were taught by using student facilitator and explaining learning with high learning independence average corrected by 55.97 It shows that the results of learning mathematics group of students who were taught using a reciprocal teaching learning model with higher learning independence is higher than the result of learning mathematics group of students who are taught using student facilitator and explaining learning model with high learning independence after controlling the initial knowledge. This means that the use of reciprocal teaching learning model which is done in this research can improve students' mathematics learning outcomes better than the use of student facilitator and explaining learning model in students with high learning independence by controlling the initial ability. The findings of this study answer the research hypothesis that for students with high learning independence, the results of learning mathematics students learning with learning models reciprocal teaching is higher than that given model student facilitator and explaining, after controlling the student's early ability.

As stated in chapter II, Reciprocal teaching emphasizes the students' active role in learning to build their understanding and develop their learning independence. The principle is in line with the basic principle of constructivism which assumes that knowledge is the construction of us knowing something. Knowledge is not a fact that lives found, but the formulation that created a person who is studying it.

While students with high levels of learning independence have characteristics: good self-control, high self-confidence, commitment to high tasks, able to solve problems, full of initiative, and able to make decisions. Students with characters or traits such as these, usually in their learning behavior will be determined by their own initiative, as it considers learning as a necessity. In addition, students who have high learning independence have a tendency to like something that is practical. This is the reason that students with high learning independence prefer reciprocal teaching learning models that require students to learn actively. This is relevant to the results of Namaghi and Shahhosseini's research indicating that although the learning model of reciprocal teaching interaction between students is more dominant than teacherstudent interaction, because in this learning model students with high learning independence are able to build their own understanding beyond what they get from teachers in class through interaction with various sources of learning outside the classroom. 
3. For students with low learning independence, the results of mathematics learning of students who are learning with the reciprocal teaching learning model is lower than that provided by the student facilitator and explaining model, after controlling the students' initial ability.

Results of $t$-test on students who have low learning independence, $t$ value $=1.83$ greater than $\mathrm{t}$ table $(0.05 ; 59)=1.67$. This means that there are differences in mathematics learning outcomes of students who study with the reciprocal teaching model and who studied with student facilitator and explaining model for groups of students who have low learning independence. Thus, it can be concluded that the result of learning mathematics of students who have low learning independence, in the group of students learning with the reciprocal teaching model is lower than the group of students who studied with student facilitator and explaining model after controlling the initial ability $(56.22<62.63)$

The matter above is in accordance with the results of mathematics learning groups of students who were taught using a reciprocal teaching learning model with low learning independence with an average corrected of 56.22 While the group of students who were taught by using student facilitation and explaining learning with low average learning independence corrected by 62.63 This shows that the results of learning mathematics group of students who were taught using a model of reciprocal teaching learning with the independence of learning lower than the result of learning mathematics group of students who were taught using student facilitator and explaining learning model with low learning independence after controlling the initial knowledge. This means that the use of student facilitator and explaining learning model in this research can improve students' mathematics learning outcomes better than the use of reciprocal teaching learning model in students with low learning independence by controlling initial ability. The findings of this study answer the research hypothesis that for students with low learning independence, the results of learning mathematics students learning with learning models reciprocal teaching is lower than the model given student facilitator and explaining, after controlling the student's early ability.

As mentioned in chapter II, the student facilitator and explaining learning model is a learning model that trains students to be able to present their ideas or ideas to their friends. This learning model can be used by teachers in the middle of the lesson in the form of collaborative learning activities that can avoid the way of teaching that is always dominated by teachers in learning in the classroom. Through collaborative learning activities (collaboration) students are expected to gain knowledge, skills, and attitudes. This opinion illustrates that students with low learning independence prefer to use student learning model facilitator and explaining, this model more demands the ability of the teacher to present or demonstrate the material in front of students and then give the students the opportunity to explain to their friends, Through learning activities collaboration (collaboration) of these students will acquire knowledge, skills, and attitudes actively.

The results of this study is supported by research conducted by Muslims, which shows that in the model of learning Student Facilitator and Explaining learners give each other opinions or ideas they have in understanding a 
problem. Critical thinking skills are explored and increased by the contribution of thoughts from other learners as well as guidance from the teacher, so that critical thinking skills obtained by learners can be applied to other concepts or similar.

\section{Conclusion} concluded

Based on the analysis and discussion by the researchers, it can be

1. The results of the students' mathematics learning group taught by the reciprocal teaching learning model were higher than the students' mathematics learning outcomes that were taught using the student facilitator and explaining model, after controlling the students' initial ability.

2. There is an interaction effect between the learning model with the independence of learning to the students' mathematics learning outcomes, after controlling the student's early ability.

3. For students with high learning independence, the results of learning mathematics of students who learn with the reciprocal teaching learning model is higher than that given model student facilitator and explaining, after controlling the student's early ability.

For students with low learning independence, the results of learning mathematics of students learning with the reciprocal teaching learning model is lower than that provided by student facilitator and explaining model, after controlling students' initial ability.

\section{Disclosure statement}

No potential conflict of interest was reported by the authors.

\section{Notes on contributors}

\section{Dodik Mulyono- STKIP-PGRI Lubuklinggau, INDONESIA}

\section{References}

Alisha Francis and Abraham Flanigan, Self-Directed Learning and Higher Education Practices: Implications for Student Performance and Engagement, The International Journal of the Scholarship of Teaching and Learning v. 7 n. 3, 2012.

Arend, I Arend, (2012), Learning to Teach, 9th Editions, New York: McGraw-HillCompanies. ISBN 978-0-07-802432-0

Dick, Walter, Carey, Lou, Carey, James O, (2009), The Systematic Design of Instruction, New Jersey: Pearson Education, Inc. ISBN 978-0-13-282485-9

Elaine B. Johnson, (2009), Contextual Teaching \& Learning; terjemahan IbnuSetiawan, Bandung: Mizan Learning Center. ISBN 0-7619-7864-X (c)

Emzir, (2008), Metodologi Penelitian Pendidikan Pendekatan Kuantitatif dan Kualitatif, Jakarta: PT Raja Grafindo Persada. ISBN 9797691624

Fridani, Lara. (2009), Ape Lestari,Inspiring Education: Kisah Inspriratis Pembelajran Anak Usia Sekolah Dasar, Bandung: Alex Media Komputindo. ISBN979273998X 
Harvey. S. Virginia and Wolfe, A. Chickie- Louise, (2007), Fostering independent learning : practical strategies to promote student successs, New York: TheGuilford Press. ISBN-13: 978-1-59385$451-5$

Jubeir Suleiman Samir Al-Harby, The Effect of Reciprocal-Teaching Strategy on LearningOutcomes and Attitudes of Qassim-University Students in "Islamic Culture", Journal of Education and Practice, Vol.7, No.6, 2016

Lie, Anita. (2010), Cooperative Learning, Jakarta: PT. Grasindo. ISBN 9789790253209

Oczkus. Lori D. (2010),Reciprocal teaching at work: powerful strategies and lessons for improving reading comprehension, Newyork: International ReadingAssociation. ISBN 978-0-87207-5078

Pallinscar, Anne marle S. and Ann L. Brown, Reciprocal Teaching Of Comprehension Fostering and Comprehension Monitoring Activities, Washington D.C: llionis-University Of liionis at Orbana-Champion, Cognition and Instruction I, 2007.

Robyn M. Gillies and Adrian F. Ashman, (2003),Co-operative Learningthe; social and intellectual outcomes of learning in groups, New York: Routledge Falmer. ISBN 0-203-46526-1 Master ebook ISBN

Seyyed Ali Ostovar-Namaghi and Mohammad-Reza Shahhosseini, On the Effect of Reciprocal Teaching Strategy on EFL Learners' Reading Proficiency, Journal of Language Teaching and Research, Vol. 2, No. 6, 2011

Siska Ryane Muslim, Pengaruh Penggunaan Metode Student Facilitator And Explaining Dalam Pembelajaran Kooperatif Terhadap Kemampuan Pemecahan Masalah Matematik Dan Kemampuan Berpikir Kritis Matematik Siswa SMK Di Kota Tasikmalaya, Jurnal Pendidikan dan Keguruan Vol. 1 No. 1, 2014.

Wiliams, Jill. (2003),Promoting independent learning in the primary classroom, Buckingham: Open University Pres. ISBN 0-335-20016-8 